\title{
Effectiveness of Ergonomic Gymnastic toward Acid Uric Level of Elderly Patients with Gout/Arthritis
}

\author{
Maria Magdalena Purba ${ }^{1}$, Widya Warastuti ${ }^{2}$ \\ ${ }^{1,2}$ Nursing Department, Poltekkes Kemenkes Palangka Raya, Indonesia
}

*Corresponding Author: Maria Magdalena Purba, Poltekkes Kemenkes Palangka Raya, Indonesia, Email:mariapurba45@gmail.com

\begin{abstract}
Background: Gout may interfere with comfort during activities due to joint pain and also cause a high risk of complications such as Urolithiasis and Nephropathy. Treatment of gout, especially those experiencing acute uric acid can be done pharmacologically and non-pharmacologically.

The Objective: The purpose of this study was to determine the effectiveness of ergonomic gymnastics on uric acid levels of elderly clients with gout/arthritis at a nursing home, in Tangkiling, Palangka Raya, Indonesia. This research is more focused on non-pharmacological therapy with ergonomic gymnastics.

Method: The research method is quasi-experiment with pre and posttest design with 25 respondents and 25 control group.

Result: The result of this research shows that there is a significant correlation between ergonomic gymnastics with decrease of uric acid level in treatment group shown by the significant value $(0.00)<p$ value (0.05)

Conclusion: Ergonomic gymnastics can maximize the supply of oxygen to the brain, sweat system, body's heating system, as well as to a combustion system such as uric acid. This way, the gymnastics provides health for the elderly so that the elderly are happy in the old days.
\end{abstract}

Keywords: Ergonomic gymnastics, uric acid, elderly, gout.

\section{BACKGROUND}

The prevalence of gout incidence is still not globally recorded in the world, but gout/arthritis is a dominant health problem in both developed and developing countries. (Hidayat 2009) suggests that the prevalence of gout is approximately $2.6-47.2 \%$ in various populations Chuang (2011), based on the results of research in Taiwan in $2005-2008$, the incidence of gout in older women increased by $19.17 \%$, and the prevalence of gout in senior women was by $23.3 \%$. Chattopadhyay et.al (2001) defines acute gout is an inflammatory disorder characterized by pain caused by monosodium uric crystal accumulation as well as soft tissue in the body. Gout is characterized by elevated uric acid levels $(>7 \mathrm{mg} / \mathrm{dl})$ in men and $(>6 \mathrm{mg} / \mathrm{dl})$ in women. In Indonesia, gout arthritis disease ranks second from osteoarthritis (Juandy, 2009). Gout can disturb the comfort when on the move due to joint pain. Besides, gout can also cause a high risk of complications such as Urolithiasis and acute uric acid Nephropathy. Handling of such complications needs to receive appropriate treatment. Fravel, \& Ernst, (2011) suggests that proper and safe handling of gout is necessary both pharmacologically and non-pharmacologically.

Exercise is an effective way to lower uric acid levels. Twenty minutes of exercise per day is recommended to keep the body fit and reduce uric acid levels (Mujianto, 2013). Gymnastics that can be done for elderly include 10 minutes gymnastics, Kegel exercises, yoga, tai-chi and ergonomic gymnastics. Therefore, researchers are interested to know the effectiveness of ergonomic gymnastics to uric acid levels of elderly clients with gout/arthritis at a nursing home in Tangkiling, Palangka Raya, Indonesia.

\section{MATERIALS AND METHODS}

This research uses a quasi -experiment method with posttest control group design which is divided into two groups. The first group was the treatment group that received ergonomic exercise 3 times a week for four weeks, and the second group was the control group, the group who received regular exercise routine every once a week. The research was conducted at 
Sinta Rangkang nursing home in Tangkiling, Palangka Raya. The reason for choosing the location is because this nursing home is the only one in the city. The population in this study is all 100 elderly in the nursing home. This way, the writers applied purposive random sampling. The inclusion criteria in this study were age 50 and above, willing to be the respondent, blood uric acid $\geq 6 \mathrm{mg} / \mathrm{dl}$ for women and men $\geq 7$ $\mathrm{mg} / \mathrm{dl}$. While exclusion criteria are elderly who are uncooperative and do not follow full activities, the old who consumes therapeutic drugs such as uric acid-lowering medicines, hypertension drugs, have other additional diseases and have a physical weakness (injury). The sample size of this study was calculated using the Slovin formula (Notoatmojo, 2010) and obtained a sample of 50 people.

\section{ReSUlts}

Subjects in this study were elderly residing in nursing home Sintang Rangkang Tangkiling amounted to 50 people consisting of 25 elderly as the treatment group and 25 older as the control group.

Table1. Distribution of Respondents' Characteristics by Gender

\begin{tabular}{|l|l|l|l|}
\hline \multirow{2}{*}{ Gender } & \multicolumn{2}{c|}{ Groups } & \multirow{2}{*}{ Total } \\
\cline { 2 - 3 } & Treatment & Control & \\
\hline Men & 13 & 18 & 31 \\
& $52 \%$ & $72 \%$ & $62 \%$ \\
\hline Women & 12 & 7 & 19 \\
& $48 \%$ & $28 \%$ & $38 \%$ \\
\hline Total & 25 & 25 & 50 \\
& $100 \%$ & $100 \%$ & $100 \%$ \\
\hline
\end{tabular}

Based on gender data, male respondents $(52 \%)$ are more than women in treatment group while in the control group men are also more than females $(72 \%)$.

Table2. Distribution of Respondents' Characteristics by Age

\begin{tabular}{|l|l|l|}
\hline \multicolumn{1}{|c|}{ Age } & \multicolumn{2}{c|}{ Groups } \\
\cline { 2 - 3 } & Treatment & Control \\
\hline Mean & 69.36 & 67.40 \\
\hline SD & 9.282 & 9.626 \\
Mini-Max & $51-90$ & $52-80$ \\
\hline
\end{tabular}

Based on Table 2 above the mean age of respondents treated was 69.39 years and the standard deviation was 9.28 while the youngest age was 51 years old, and the oldest was 90 years.

Levels of uric acid in the treatment group and control group were assessed through checks performed before ergonomic exercise and after completion of exercises performed three times a week for four weeks for treatment group and one week per day for the control group.
Table3. Description of Uric Acid Levels before and after Ergonomic Exercise

\begin{tabular}{|c|c|c|c|c|}
\hline \multirow{2}{*}{ Statistic } & \multicolumn{2}{|c|}{$\begin{array}{c}\text { Treatment } \\
\text { Group } \\
\mathbf{n}=\mathbf{2 5}\end{array}$} & \multirow{2}{*}{$\begin{array}{l}\begin{array}{l}\text { Control } \\
\text { Group } \\
\mathbf{n}=\mathbf{2 5}\end{array} \\
\text { Levels } \\
\text { of } \\
\text { uric } \\
\text { acid } \\
\text { before } \\
\text { regular } \\
\text { gymnast } \\
\text { ics }\end{array}$} & \multirow[b]{2}{*}{$\begin{array}{l}\text { Levels } \\
\text { of uric } \\
\text { acid } \\
\text { after } \\
\text { regular } \\
\text { gymna } \\
\text { stics }\end{array}$} \\
\hline & $\begin{array}{l}\text { Levels } \\
\text { of } \\
\text { uric } \\
\text { acid } \\
\text { before } \\
\text { ergono } \\
\text { mic } \\
\text { gymna } \\
\text { stics }\end{array}$ & $\begin{array}{l}\text { Levels } \\
\text { of } \\
\text { uric } \\
\text { acid } \\
\text { after } \\
\text { ergono } \\
\text { mic } \\
\text { gymnast } \\
\text { ics }\end{array}$ & & \\
\hline Mean & 7.66 & 6.43 & 7.9 & 8.01 \\
\hline $\begin{array}{l}\text { Std } \\
\text { Dev }\end{array}$ & 1.052 & 1.048 & 1.49 & 1.52 \\
\hline $\begin{array}{l}\text { Minimu } \\
\mathrm{m}\end{array}$ & 6.2 & 4.4 & 6.0 & 6.0 \\
\hline $\begin{array}{l}\text { Maximu } \\
\mathrm{m}\end{array}$ & 10 & 9.0 & 11.5 & 11.5 \\
\hline Range & 3.8 & 4.6 & 5.5 & 5.5 \\
\hline
\end{tabular}

These data suggest that uric acid levels between treatment groups and controls are not significantly different. The difference in the mean value of uric acid levels before ergonomic gymnastics and regular exercise between treatment groups and the control group was 0.24 .

Homogeneity test aims to find out whether the variance of the research data homogeneous or not homogeneous. When the results of this test obtained $p$-value ( $p>0.05$ ), then the value of the variance is homogeneous. The following table shows homogeneity test between treatment group and control group.

Table4. Homogeneity test of uric acid levels before and after ergonomic gymnastics and regular gymnastics

\begin{tabular}{|c|c|c|c|c|c|}
\hline \multirow{2}{*}{ Variables } & \multicolumn{2}{|c|}{$\begin{array}{c}\text { Treatment } \\
\text { Group } \\
\mathbf{n = 2 5}\end{array}$} & \multicolumn{2}{|c|}{$\begin{array}{c}\text { Control } \\
\text { Group } \\
\mathbf{n = 2 5}\end{array}$} & \multirow{2}{*}{ Sig. } \\
\cline { 2 - 5 } & mean & SD & mean & SD & \\
\hline $\begin{array}{c}\text { Uric acid levels } \\
\text { before test }\end{array}$ & 7.66 & 1.052 & 7.9 & 1.49 & 0.52 \\
\hline $\begin{array}{c}\text { Uric acid levels } \\
\text { after test }\end{array}$ & 6,4 & 1.04 & 6.4 & 1.04 & 0.97 \\
\hline Men & 8.2 & 1.23 & 7.7 & 1.41 & \\
\hline Women & 7.1 & 1.07 & 6.45 & 1.38 & \\
\hline
\end{tabular}

From the above table, it is shown that this research data is homogeneous where significant value> of value $(\mathrm{p}>0.05)$

Paired Test Sample Test / T-test are conducted to determine whether there is a significant relationship between ergonomic gymnastics with decreased levels of uric acid in the treatment group. 
Table5. Changes in average uric acid levels before and after gymnastics ergonomics and regular gymnastics

\begin{tabular}{|l|l|l|l|}
\hline \multirow{2}{*}{ Variable } & \multicolumn{2}{|l|}{ Pair t-test difference } & Sig. \\
\cline { 2 - 4 } & mean & SD & \\
\hline Uric acid levels & 7.78 & 1.28 & 0.00 \\
before test & 7.22 & 1.52 & \\
Uric acid levels & & & \\
after test & & & \\
\hline
\end{tabular}

In the table above uric acid levels after ergonomic exercise in the treatment group decreased from 7.78 to 7.22 . From the table, it can be explained that there is a significant relationship between ergonomic gymnastics with reduced uric acid in treatment group seen from the value of $\mathrm{sig}(0.00)<\mathrm{p}$ value $(0.05)$. Thus, it is concluded that ergonomic gymnastics is effective in decreasing uric acid levels in the blood.

\section{DISCUSSION}

Characteristics of research subjects indicated that the highest proportion was male. This condition is because the number of elderly in the nursing home is more male than female. Out of the 100 older adults in the nursing home, 55 were men and also samples who fulfilled the criteria and were willing to follow this study were more men. This is reinforced by Choi et.al (2004) who argued that gout tends to be experienced by men because men do not have estrogen hormones so that at puberty age more people experience gout than women. This occurrence is in agreement with Kertia (2009) who argued that the older the male, the higher the possibility of gout disease. Doherty (2009) also said that gout is more suffered by men than women at the ratio 4: 1 at age 65 and above. These results suggest that the prevalence of gout in men is greater than in women, which is $21.6 \%$ in males and 8.6 in females.

The elderly tend to experience gout caused by a decrease in the production of some enzymes and hormones in the body that play a role in the excretion of uric acid. The enzyme that plays a role in uric acid excretion process is urokinase enzyme. This enzyme serves to convert uric acid into the alotonin form which will be excreted through urine. As a result, disruption of urination enzyme will affect the discharge of uric acid that can cause gout. The result of data analysis shows that there is a significant change between ergonomic gymnastics and uric acid level of the respondent of treatment group which is proved by sig. Value $(0.00)<\mathrm{p}$-value $(0.05)$. This result follows Komariah (2015) stating that uric acid levels fell -1.251 during four weeks of exercise. The difference of this study with previous research is on the examination of uric acid levels as this research uses photometer $5010 \mathrm{v} 5+$. The results of this study showed that ergonomic gymnastics actually reduce uric acid levels because ergonomic gymnastics is a technique of exercise to restore or correct the position and flexibility of the nervous system and blood flow. Ergonomic gymnastics also maximizes oxygen supply to the brain, opens up the system of intelligence, sweat, body heat, and burning (uric acid, cholesterol, blood sugar, lactic acid, oxalate crystals). Besides ergonomic gymnastics can help the carbohydrate conversion system, making electrolytes in the blood, body freshness, and immune from negative energy/virus, and the discharge of negative energy from the body. Movement contained in ergonomic gymnastics is a very effective, efficient and logical move because the series of action is a series of prayer movements which humans have done since the first to date (Sagiran, 2012). Ergonomic Gymnastics is a gymnastics that can instantly open, clean and activate the entire nervous system of the body. This result is also supported by research by Suharjono (2014) which found that ergonomic gymnastics affect the decrease of pain caused by gout.

\section{CONCLUSION}

The result of data analysis shows that there is a significant influence between ergonomic gymnastics with decreasing the uric acid level of elderly in nursing home Rangkang Tangkiling, Palangka Raya, Indonesia. It is recommended to educate the public that physical exercise can improve health, especially physical activity with ergonomic gymnastics that is proven effective in lowering uric acid levels in the blood.

\section{REFERENCES}

[1] Chattopadhyay, I., Shetty, H. G. M., Routledge, P. A., \& Jeffery, J. (2001). Colchicine induced rhabdomyolysis. Postgraduate medical journal, 77(905), 191-192.

[2] Chuang, S. Y., Lee, S. C., Hsieh, Y. T., \& Pan, W. H. (2011). Trends in hyperuricemia and gout prevalence: Nutrition and Health Survey in Taiwan from 1993-1996 to 2005-2008. Asia Pacific journal of clinical nutrition, 20(2), 301308.

[3] Choi, H. K., Atkinson, K., Karlson, E. W., Willett, W., \& Curhan, G. (2004). Purine-rich foods, dairy and protein intake, and the risk of gout in men. New England Journal of Medicine, 350(11), 1093-1103.C 
[4] Doherty, M. (2009). New insights into the epidemiology of gout. Rheumatology, 48 (suppl_2), ii2-ii8.

[5] Fravel, M. A., \& Ernst, M. E. (2011). Management of gout in the older adult. The American journal of geriatric pharmacotherapy, 9(5), 271-285.

[6] Hidayat, R. (2009). Gout dan hiperurisemia. Medicinus. Edisi Juni-Agustus;22:47- 50

[7] Juandy, J. (2009). Gout dan Diet, http://www. depkes.go.id/

[8] Komariah, A. (2015) Pengaruh Senam ergonomis Terhadap Kadar Asam Urat Pada Lansia dengan Gout di Pos Binaan Terpadu Kelurahan Pisangan Ciputat Timur. (Thesis unpublished).
[9] Kertia, N. (2009). Asam Urat: Benarkah Hanya Menyerang Laki-laki. Yogyakarta: B Frirs.

[10] Mujianto. 2013. Cara Cepat Mengatasi 10 Besar Kasus Muskuloskeletal dalam Praktek Klinik Fisioterapi. Malang: Tim Press.

[11] Notoatmodjo, S. (2010). Metodologi Penelitian Kesehatan. Jakarta: Rineka Cipta.

[12] Sagiran. (2012). Mukjizat Gerakan Sholat. Jakarta : Qultum Media

[13] Suharjono (2014). Pengaruh Senam Lansia Terhadap Perubahan Nyeri Persendian Pada Lansia di Kelurahan Komplek Kenjeran, Kecamatan Bulak, Surabaya. Jurnal Ilmiah, 2 (2), 106-110.

Citation: Maria Magdalena Purba \& Widya Warastuti, Effectiveness of Ergonomic Gymnastic toward Acid Uric Level of Elderly Patients with Gout /Arthritis. ARC Journal of Public Health and Community Medicine. 2017; 2(3):21-24 doi:dx.doi.org/10.20431/2456-0596.0203004

Copyright: (C) 2017 Authors. This is an open-access article distributed under the terms of the Creative Commons Attribution License, which permits unrestricted use, distribution, and reproduction in any medium, provided the original author and source are credited. 